\title{
Precipitation Protocol Optimization for Trace Amounts of DNA
}

E.K. Wheeler, A.M. Erler, A.Seiler

August 31, 2007 


\section{Disclaimer}

This document was prepared as an account of work sponsored by an agency of the United States government. Neither the United States government nor Lawrence Livermore National Security, LLC, nor any of their employees makes any warranty, expressed or implied, or assumes any legal liability or responsibility for the accuracy, completeness, or usefulness of any information, apparatus, product, or process disclosed, or represents that its use would not infringe privately owned rights. Reference herein to any specific commercial product, process, or service by trade name, trademark, manufacturer, or otherwise does not necessarily constitute or imply its endorsement, recommendation, or favoring by the United States government or Lawrence Livermore National Security, LLC. The views and opinions of authors expressed herein do not necessarily state or reflect those of the United States government or Lawrence Livermore National Security, LLC, and shall not be used for advertising or product endorsement purposes.

\section{Auspices Statement}

This work performed under the auspices of the U.S. Department of Energy by Lawrence Livermore National Laboratory under Contract DE-AC52-07NA27344. 


\section{Preface:}

This report describes work funded by the Department of Homeland Security as part of the Forensics and Attribution Thrust Area in DHS' Biocountermeasures Portfolio. It is submitted to the sponsoring DHS program office as a deliverable for the FY06 Sample Management Task titled "In-Bed Purification and Amplification of Trace DNA from Contaminated Liquids" (PEP 1.2.2.14.1.7.4.3.2). The Task PI and corresponding technical author is Elizabeth Wheeler. LLNL's Sample Management program contact is David Camp.

Dr. Elizabeth Wheeler, LLNL

L-223; POB 808

Livermore, CA 94551

wheeler16@1lnl.gov

925-423-6245

Dr. David W. Camp, LLNL

L-172; POB 808

Livermore, CA 94551

camp2@1lnl.gov

925-423-9228 


\title{
Precipitation Protocol Optimization for Trace Amounts of DNA
}

\author{
Elizabeth Wheeler, Anne Erler, Amanda Seiler \\ Lawrence Livermore National Laboratory \\ August 31, 2007
}

\begin{abstract}
Excecutive Summary
The goal of the work reported here was to optimize an ethanol precipitation protocol for applications in which there is a low number of DNA copies. Starting with an NBFAC-prescribed initial protocol, we tested variations suggested by the literature and arrived at an improved protocol. The result is a recommended procedure for ethanol precipitation of samples containing trace quantities of DNA. It is detailed in Appendix B. Millipore Microcon spin columns were also evaluated, and found to be much less efficient than our recommended precipitation protocol.
\end{abstract}

\section{Introduction}

\section{Project Motivation}

Previous work compared the lower limits of detection (LOD) of B. anthracis obtained with Qiagen spin columns with those obtained from the packed bed surface amplification developed by LLNL ${ }^{1}$. Upon further review of these procedures, it was unclear whether the lower LODs exhibited by the packed bed technology were due to minimization of sample losses or the fact that the entire sample, rather than an aliquot, was used during the PCR analysis.

In this project, we were asked to perform follow-up experiments to analyze the entire eluted product from the Qiagen spin columns. Upon elution from the Qiagen columns, an ethanol precipitation step was required to reduce the number of PCR reactions needed to analyze the entire sample. DNA precipitation is extremely challenging in low copy number applications.

As part of this, we began a side-task having the initial goal to find the optimal final volume for a prescribed ethanol precipitation protocol. As work progressed we saw an opportunity to also optimize the precipitation protocol. This report details the initial precipitation protocol that we used and the rationale for the final protocol we used and recommend.

\section{Initial precipitation protocol}

Working with NBFAC we established the initial precipitation protocol, detailed in Appendix A (based on email discussions finalized on 08 Aug 2006).

Only a subset of the previously-analyzed samples were to be compared in these experiments. Known amounts of $B$. anthracis DNA, from 10 to $0.01 \mathrm{pg}$, were spiked into $100 \mu \mathrm{L}$ of: a) water and b) carpet extract in DI water. These spiked samples were processed through: a) Qiagen spin columns followed by the precipitation detailed in Appendix A and b) packed beds. Details of the liquid DNA and spiking procedures are found in our June 2006 report. ${ }^{1}$ Ten replicates of the Qiagen columns at each starting concentration of DNA were analyzed. We also modified the PCR protocol to allow the addition of $5 \mu \mathrm{L}$ of sample, compared to $2 \mu \mathrm{L}$ that was used in the 
previous study. Since this report focuses on the precipitation protocol, the specific results for both the Qiagen/precipitation and packed bed processes are discussed in another report.

Using the initial precipitation protocol, the precipitated Qiagen spin column extracts showed worse limits of detection than $2 \mu \mathrm{L}$ aliquots of the unconcentrated extract. These disappointing results prompted a detailed investigation into the effects of all the parameters in the ethanol precipitation protocol.

\section{Literature Review}

A more detailed survey of the internet and literature found two interesting quantitative studies regarding precipitation protocols and their percent recoveries. Both studies that we found investigated the percent recovery of DNA over a range of concentrations $(10 \mathrm{ng} / \mathrm{mL}-1 \mu \mathrm{g} / \mathrm{mL})$ as a function of incubation time and temperature. The data illustrate, as expected, that percent recovery decreases with decreasing initial concentration. These two bodies of work agreed in general conclusions and provided guidance on how to further optimize our ethanol precipitation protocol.

The first source for quantified precipitation data came from a paper in Analytical Biochemistry. ${ }^{2}$ The overall finding of this work was that ultracentrifugation methods could yield greater that $70 \%$ recovery of DNA and that "Poor recovery of the nucleic acids appears due to the fact that small amounts of nucleic acids do not adhere to the tubes following sedimentation unless ultracentrifugation is employed." While we were not directly interested in the ultracentrifugation results, the efficiency of the author's standard centrifugation methods aided us in modifying our own precipitation protocol. A summary of these comparisons is reproduced in Table 1.

\begin{tabular}{|l|c|c|c|c|c|}
\hline & \multicolumn{5}{|c|}{$\%$ Recovery per DNA concentration } \\
\hline & $10 \mathrm{ng} / \mathrm{mL}$ & $25 \mathrm{ng} / \mathrm{mL}$ & $50 \mathrm{ng} / \mathrm{mL}$ & $250 \mathrm{ng} / \mathrm{mL}$ & $1 \mu \mathrm{g} / \mathrm{mL}$ \\
\hline EtOH, $-20^{\circ} \mathrm{C}, 24 \mathrm{hr}$ & 41 & 64 & 36 & 72 & 81 \\
\hline EtOH, $-70^{\circ} \mathrm{C}, 2 \mathrm{hr}$ & 7 & 13 & 19 & 25 & 57 \\
\hline EtOH, $-70^{\circ} \mathrm{C}, 24 \mathrm{hr}$ & 38 & 53 & 41 & 64 & 69 \\
\hline
\end{tabular}

Table 1: Comparison of different ethanol precipitation protocols for varying starting concentrations of DNA. Reproduced from reference 2.

We also found quantitative data for ethanol precipitations on the Millipore web page. The Millipore web page presented the following data summarizing the percentage recovery for varying DNA concentrations, Table 2. This data was generated in triplicate for starting volumes of $250 \mu \mathrm{L}$ that were concentrated to $50 \mu \mathrm{L}$. The Millipore work showed that if the starting concentration of DNA is $10 \mathrm{ng} / \mathrm{mL}$ the best case scenario only yields a $31 \%$ recovery of DNA after precipitation. 


\begin{tabular}{|l|c|c|c|c|c|}
\hline & \multicolumn{5}{|c|}{ \% Recovery per DNA concentration } \\
\hline & $10 \mathrm{ng} / \mathrm{mL}$ & $25 \mathrm{ng} / \mathrm{mL}$ & $50 \mathrm{ng} / \mathrm{mL}$ & $250 \mathrm{ng} / \mathrm{mL}$ & $1 \mu \mathrm{g} / \mathrm{mL}$ \\
\hline EtOH, $-70^{\circ} \mathrm{C}, 15 \mathrm{~min}$ & 14 & 15 & 23 & 52 & 55 \\
\hline EtOH, $-20^{\circ} \mathrm{C}, 30 \mathrm{~min}$ & 13 & 20 & 25 & 60 & 72 \\
\hline EtOH, $-20^{\circ} \mathrm{C}, 18 \mathrm{hr}$ & 31 & 45 & 45 & 76 & 67 \\
\hline
\end{tabular}

Table 2: Data from Millipore web page. ${ }^{3}$

Figure 1 shows all of the literature review data in graphical form. Solid symbols in Figure 1 represent precipitations with long incubation times $(\geq 18 \mathrm{hr}$ ), while open symbols represent short incubation times $(\leq 2 \mathrm{hr})$ Using standard centrifugation ethanol precipitation methods shows a declining recovery rate as a function of the decreasing starting concentration of DNA. The region of interest for our follow-on experiments with Qiagen spin columns ( $10 \mathrm{pg}$ to $10 \mathrm{fg}$ in $100 \mu \mathrm{L}$ ) is shown to the left of the dashed line. Projecting the observed recovery trend to the concentration regime we are interested in predicts very low percent recovery.

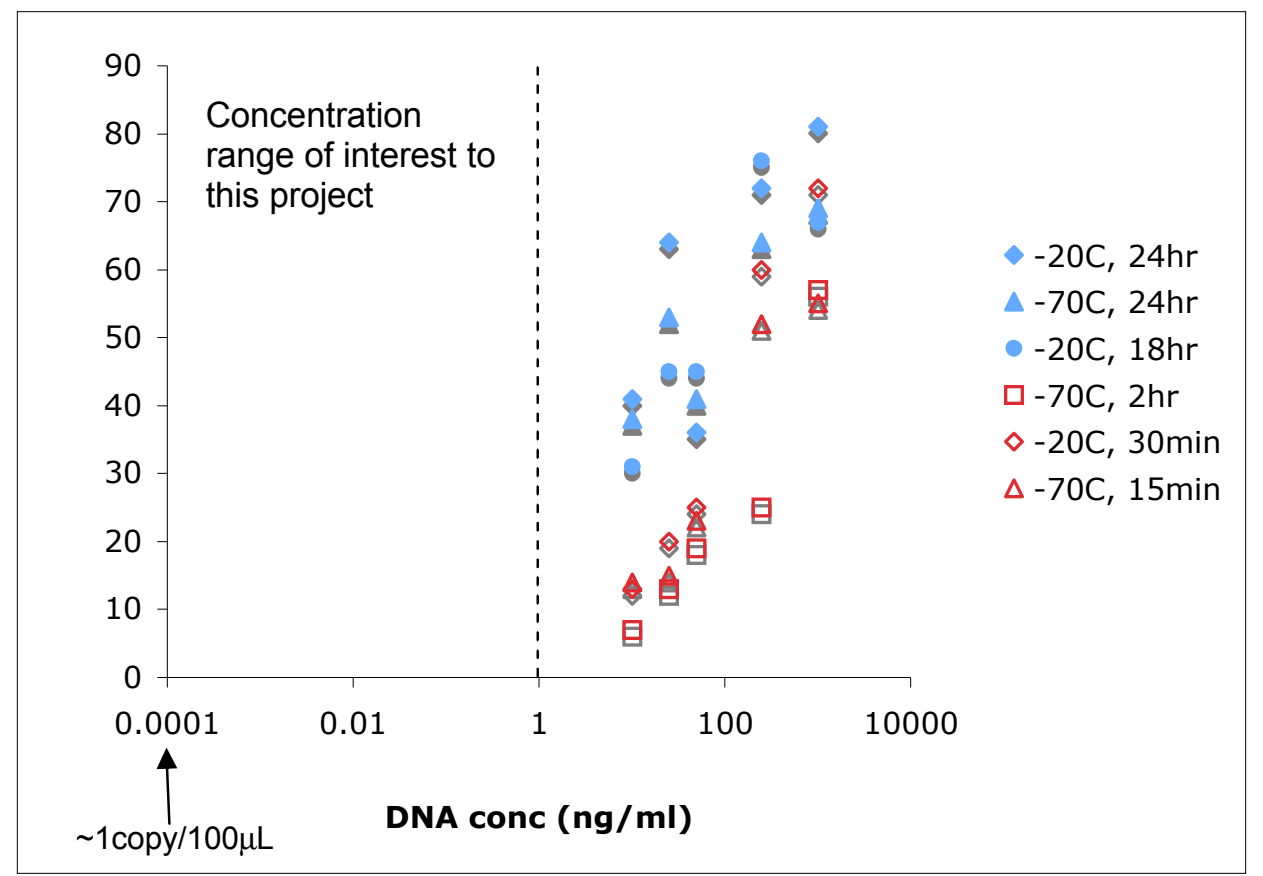

Figure 1: Summary of all data from literature studies. Open symbols represent data with short incubation times. Solid symbols represent long incubation times $(\geq 18 \mathrm{hrs})$ 
It should be noted that the concentration range studied in references 1 and 2 is several orders of magnitude higher than the concentration ranges we were interested in for this project. As a reference point, if 1pg (approx. 100 copies) of DNA in 100ul is processed through a Qiagen spin column with $100 \%$ efficiency this would correspond to a concentration of $0.01 \mathrm{ng} / \mathrm{ml}, 3$ to 5 orders of magnitude lower than the data range studied in these previous works.

In summary, we drew three general conclusions from the previous precipitation studies:

1. Over the range of concentrations studied, the percent recovery decreased with decreasing starting concentration

2. Incubating for longer times (18 or 24 hours) yielded better recoveries for lower starting concentrations

3. Incubating at $-20^{\circ} \mathrm{C}$ or $-70^{\circ} \mathrm{C}$ showed no significant difference

\section{Millipore Microcon Spin Columns for Concentration}

Ironically, Millipore sells their own concentration columns. We did purchase and evaluate these columns (Microcon YM-10 Cat\#42421). Although the Millipore products were faster than an overnight precipitation, the recovery was very low for trace applications in the concentration ranges of interest. Table 3 presents a comparison of the Millipore Microcon columns to an overnight ethanol precipitation.

\begin{tabular}{|c|c|c|}
\hline & \multicolumn{2}{|c|}{ \% Recovery } \\
\hline Amt DNA (pg) & Overnight Precipitation & Millipore Column \\
\hline 10 & 82 & 16 \\
\hline 1 & 93 & 49 \\
\hline 0.1 & 27 & 0.42 \\
\hline
\end{tabular}

Table 3: Comparison of Millipore Microcon spin columns to overnight precipitation.

\section{Revised Precipitation Protocol}

Based on the above literature survey and our results, we revised our precipitation protocol. The protocol is detailed in Appendix B.

To summarize, the main changes were:

- Incubated precipitation at $-20^{\circ} \mathrm{C}$ overnight

○ Overnight was typically 17-20 hours

○ This lengthening of the incubation step was based on further survey of the literature as well as our own experimental results

- Added glycogen to DNA suspension prior to adding ethanol

- Previous precipitation protocols used in our lab had used glycogen to act as a carrier, helping to precipitate the DNA. Glycogen is an alternative to adding carrier DNA. 
- Protocols for adding glycogen were also found from Ambion and Fermentas Life Sciences

- Resuspended DNA pellet overnight in PCR grade water

- Note water was chosen over TE

- TE is a chelating agent which sequesters di- and trivalent cations. This chemical property is beneficial for long term storage of DNA samples (where you don't what enzymatic activity to degrade your samples), but not for PCR (which requires enzymatic activity). Since the resuspended samples in our protocol were going directly in a PCR reaction, we chose to resuspend in water to prevent any PCR inhibition.

- The resuspension time was increased to overnight after an initial brief vortex

\section{Experimental}

Known amounts of DNA were spiked into $100 \mu \mathrm{L}$ of water, which was our starting point for the ethanol precipitation studies.

All experiments were performed with Bacillus anthracis DNA. More detailed information on the DNA source used for the Qiagen columns can be found in our final report from June $2006 .{ }^{1}$ For the Qiagen processed samples the DNA stock was quantified at $179 \mathrm{ng} / \mu \mathrm{L}$. The majority of the work focusing on the ethanol precipitation used extracted Ba DNA from the Critical Reagents Program (CRP). The Ba DNA from the CRP had at an initial concentration of 770 $\mathrm{pg} / \mu \mathrm{L}(\mathrm{D} 2005259004)$.

\begin{tabular}{lr} 
PCR Mix & \\
PCR Master mix & \\
UDG Supermix & 12.5 \\
BA F/R (10uM) & 1 \\
BA.P (5uM) & 1 \\
Water & 4.5 \\
Template & 5 \\
\hline Total & $\mathbf{2 5 \mu \mathrm { L }}$
\end{tabular}

PCR thermal cycling consisted of a conservative 3-step PCR and is detailed in our previous June final report along with details on quantitative PCR. ${ }^{1}$

\section{Precipitation Protocols}

See Appendices A and B

\section{Results and Discussion}

Table 4 shows average DNA recoveries by the initial and improved precipitation protocols at 5 $\mu \mathrm{L}$ and $10 \mu \mathrm{L}$ volumes. Although these averages suggest that the improved protocol is much better only for low copy numbers and $5 \mu \mathrm{L}$ volume, the reproducibility was much better for the improved protocol. Using our revised precipitation protocol (Appendix B) we determined that 
resuspending in $10 \mu \mathrm{L}$ gave a higher and more reproducible recovery than resuspending in only 5 $\mu \mathrm{L}$, see Table 4. What is not represented in Table 4 is the fact that the revised precipitation protocol at $10 \mu \mathrm{L}$ yielded more reproducible results than either the initial protocol or the revised method at $5 \mu \mathrm{L}$.

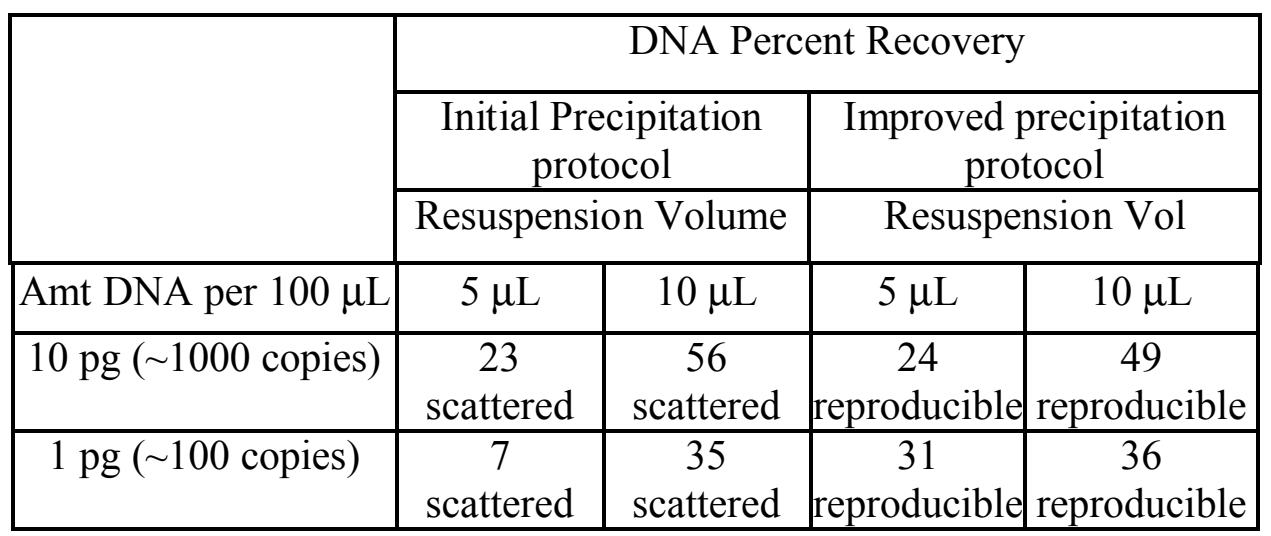

Table 4: Comparison of average percent recovery for two different resuspension volumes. Note: processes were run in triplicate for each data point. The improved protocol and concentrating to $10 \mu \mathrm{L}$ improved the reproducibility. More data points need to be collected for better statistical analysis. Percent recoveries were computed from average $\mathrm{Ct}$ for each data point in table.

Details of the comparisons between Qiagen spin columns, with and without precipitation, and LLNL's packed bed technology are given in a separate report. Table 5 summarizes the effects of the different precipitation protocols and the ability to detect DNA in Qiagen spin column extracts. Results are reported in the number of PCR reactions that successfully detected DNA for varying starting mass of DNA in water input to the Qiagen spin column. As can be seen in Table 5, the initial precipitation protocol used yielded worse limits of detection than when no concentration was performed. Interestingly, using the revised protocol did not improve the overall limit of detection (still $100 \mathrm{fg}$ for both with and without concentration) but did improve the limit at which 100\% of columns were successfully detected with PCR ( 1 pg for w/ concentration and $>10 \mathrm{pg} \mathrm{w} / \mathrm{o}$ concentration).

\begin{tabular}{|l|c|c|l|}
\hline $\begin{array}{l}\text { Amt DNA } \\
\text { input to Qiagen } \\
\text { spin column }\end{array}$ & $\begin{array}{c}\text { No } \\
\text { precipitation }\end{array}$ & $\begin{array}{c}\text { Initial } \\
\text { protocol }\end{array}$ & $\begin{array}{l}\text { Revised } \\
\text { protocol }\end{array}$ \\
\hline $10 \mathrm{pg}$ & $9 / 10$ & $5 / 10$ & $10 / 10$ \\
\hline $1 \mathrm{pg}$ & $4 / 10$ & $5 / 10$ & $10 / 10$ \\
\hline $100 \mathrm{fg}$ & $2 / 10$ & 0 & $2 / 10$ \\
\hline $10 \mathrm{fg}$ & $0 / 10$ & 0 & $0 / 10$ \\
\hline
\end{tabular}


Table 5: Comparison of \# successful PCR reactions for a given starting mass of DNA in water when processed through a Qiagen column and followed with an ethanol precipitation.

In performing these precipitation protocols two obvious tradeoffs become apparent. The first tradeoff to consider is DNA concentration versus percent recovery. Higher recovery percentages were obtained by concentrating to $10 \mu \mathrm{L}$ instead of $5 \mu \mathrm{L}$. But higher concentrations of DNA were obtained by concentrating to $5 \mu \mathrm{L}$. For example, if an ethanol precipitation (App. B protocol) is performed on 1000 copies $(10 \mathrm{pg})$ then per $5 \mu \mathrm{L}$ PCR reaction volume there are 31 copies for the $5 \mu \mathrm{L}$ resuspension volume but only 18 copies for the $10 \mu \mathrm{L}$ resuspension volume. For the lowest limit of detection, we recommend a $5 \mu \mathrm{L}$ volume. If duplicate analyses or an archive sample is desired, then a $10 \mu \mathrm{L}$ volume makes sense.

Since the precipitation protocol we finalized on (App. B) has two overnight steps, the second tradeoff is time-efficiency/recovery. The time-efficiency/recovery tradeoff should be evaluated for each application that requires an ethanol precipitation step for concentration. We chose to favor increased recovery rather than minimizing the overall processing time.

\section{Conclusion}

Based on our own experimental results and the literature, we found that our initial precipitation protocol needed to be modified before it could be reproducibly and efficiently applied to the Qiagen spin column elutant. The detailed protocol is given in Appendix B. The key modification was to incubate at $-20^{\circ} \mathrm{C}$ overnight.

\section{References}

1. K. Sorensen, E. Arroyo, A.M. Erler, A.T. Chrisitan, D. Camp, E.K. Wheeler, comparison of Packed Beds and Qiagen Columns for Recovering Trace Amounts of B. anthracis DNA from Liquid Suspensions," UCRL-TR-222387 submitted to NBFAC June 30, 2006.

2. D. Shapiro, "Quantitative Ethanol Precipitation of Nanogram Quantities of DNA and RNA, "Anal. Biochem. 110, 229-331, (1981).

3. "Quantitative Recoverires of Nanogram Amounts of Nucleic Acids with Microcon Centrifugal Filters," www.millipore.com/publications.nsf/docs/6d1139 


\section{Appendix A: Initial Prescribed Precipitation Protocol}

1. Starting precipitation sample was $100 \mu \mathrm{L}$ output of Qiagen spin column

2. Add $30 \mathrm{ul} 3 \mathrm{M} \mathrm{NaOAc} \& 300 \mu \mathrm{L}$ ice cold $100 \% \mathrm{EtOH}$

3. Incubate for $2 \mathrm{hrs}$ at $-20 \mathrm{C} *$

4. Spin at $14,000 \mathrm{rpm}$ for $30 \mathrm{mins}$ at $4 \mathrm{C}$

5. Aspirate $\mathrm{EtOH}$

6. Wash w/ $330 \mu \mathrm{L} 70 \% \mathrm{EtOH}$

7. Centrifuge at max speed for 15 mins at $4 \mathrm{C}$

8. Aspirate and repeat EtOH wash if necessary

9. Air dry DNA pellet for 10 minutes

10. Resuspend in 20,10 or $5 \mu \mathrm{L}$ TE buffer

* The initial prescribed protocol was for either $-70^{\circ} \mathrm{C}$ for 30 min or $2 \mathrm{hrs}$ at $-20^{\circ} \mathrm{C}$ 


\section{Appendix B: Recommended Precipitation Protocol}

1. To $100 \mu \mathrm{L}$ solution containing DNA

2. Add $11 \mu \mathrm{L} 3 \mathrm{M} \mathrm{NaOAc}, 1 \mu \mathrm{L}$ glycogen $(20 \mu \mathrm{g} / \mu \mathrm{L}), \& 275 \mu \mathrm{L}$ ice cold $100 \% \mathrm{EtOH}$

3. Incubate overnight $(17-20 \mathrm{hrs})$ at $-20^{\circ} \mathrm{C}$

4. Centrifuged at $14,000 \mathrm{rpm}$ for $30 \mathrm{mins}$ at $4^{\circ} \mathrm{C}$ on Beckman Coultier centrifuge

5. Aspirate $\mathrm{EtOH}$

6. Wash w/ $500 \mu \mathrm{L} 70 \% \mathrm{EtOH}$

7. Centrifuge at $14,000 \mathrm{rpm}$ for $15 \mathrm{mins}$ at $4^{\circ} \mathrm{C}$

8. Aspirate EtOH until the pellet is just covered

9. Air dry DNA pellet for 10 minutes

a. To prevent PCR inhibition, DNA pellet must dry completely

10. Resuspend in $5 \mu \mathrm{L}$ or $10 \mu \mathrm{L}$ PCR grade $\mathrm{H} 2 \mathrm{O}$ overnight (17-20 hrs)

a. Briefly vortex to dislodge and adequately disperse the pellet throughout volume of liquid

b. Note, smaller resuspension volumes result in more DNA loss, but higher DNA concentrations.

Notes:

All precipitation steps were performed in a $1.5 \mathrm{~mL}$ tube. After resuspension, DNA was transferred to PCR master mix in different tubes. 